Unity Journal

Vol. III, 195-204, 2022

Doi: https://doi.org/10.3126/unityj.v3i01.43325

Prithvi Narayan Shah Research Center

Directorate General of Military Training, Nepali Army

Kathmandu, Nepal

\title{
A Discourse on Nepal Army's Role in Conservation
}

Anu Rai

\section{Abstract}

Nepal prides itself as a conservation success story. Credit goes to the Nepal Army for their involvement in multiple conservation activities. They are at the forefront of conservation work in Nepal being stationed in the protected areas and involved in tracking down wildlife trade, controlling encroachment and deforestation, supporting rehabilitation of wild species, and much more. The results are visible having achieved zero poaching years of rhinos and other endangered species. The Nepal Army has thereby provided a great conservation service. But there is a lack of review on how their involvement has been perceived. This review represents this duality of the role of the Nepal Army in conservation arena. It has mainly been divided into three parts: Part I delves into Nepal's conservation overview, Part II highlights the role undertaken by the Nepal Army in conservation and their impact on the local communities residing around the protected areas, and Part III presents views on rethinking the engagement. For this, google scholar was examined to obtain relevant papers using a combination of search keywords - "Nepal Army", "Nepal military", "conservation Nepal", "civilmilitary relations Nepal" or its derivatives. Additional papers and newspaper articles pertaining to conservation discourse were also reviewed. Informal interviews with the Sonaha communities near the community forest of Bardiya National Park was also conducted. The review suggests that there is a need to rethink Nepal Army's involvement in conservation for promoting inclusive conservation and maintaining amicable civilmilitary relationships.

Keywords: Conservation in Nepal, Nepal Army, Army for conservation, wildlife protection, Civil-Military Relations, park people relationship, Indigenous people's right

\section{Introduction}

Set to become the first nation in the world to increase wild tiger population by two times is just one of the many conservation success stories in Nepal. Nepal has also made global headlines for achieving zero poaching of its three flagship species: tigers, rhinos and elephants. In all these efforts, Nepal Army has played a crucial role. They are also at the forefront for conservation work in Nepal such as controlling deforestation, supporting rehabilitation of wild species, and much more. This is the front explaining conservation achievement in Nepal but let's take a deeper dive into the issue.

In an elitist view, it is very easy to imagine conservation where the people inside the 
boundary have been removed to achieve maximum level of protection. This had been the way of thinking for early pioneers in conservation. From the forceful murder and evacuation of Red Indians from the Yellowstone National Park in the United States, this path had been chartered. Nepal followed a similar approach leading up to the forceful evacuation of hundreds of indigenous groups of Tharus from Chitwan National Park or Sonahas from Bardiya National Park. Many of these indigenous groups have remained landless and have been living in informal settlements where they continue to face the risk of further forced evictions (Amnesty International \& CSRC, 2021). Many of these parks are operated by the involvement of Nepal Army. The blend of military activities and conservation makes for a complex often ambivalent relationship.

Outlining the duality of the role of the Nepal Army in conservation arena, the paper attempts to present a discourse on Nepal Army's role in conservation. It mainly comprises three parts. First, a conservation overview of Nepal has been provided. The second highlights Nepal Army's role in conservation. Finally, the third part presents views on rethinking their engagement in conservation arena.

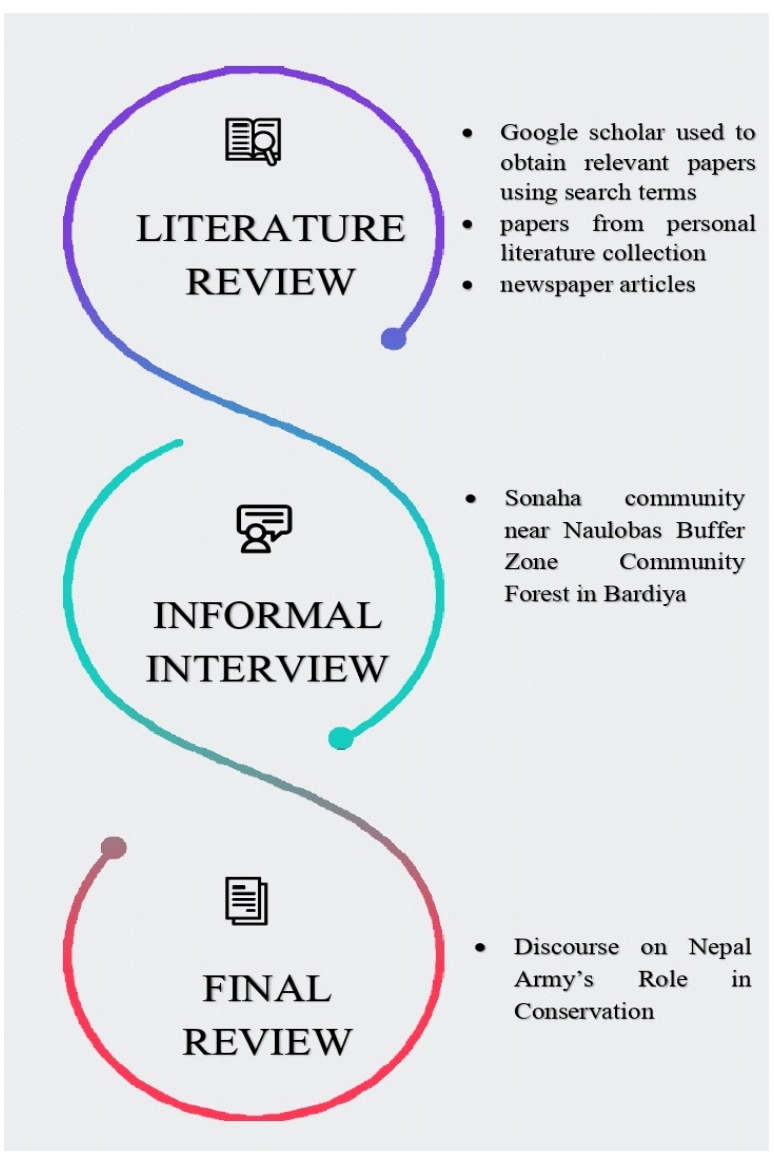

For this, google scholar was examined to obtain relevant papers using a combination of search keywords "Nepal Army", "Nepal military", "conservation Nepal", "civil-military relations Nepal" or its derivatives. Additional papers and newspaper articles pertaining to conservation discourse were also reviewed.

Informal interviews with the Sonaha community near Naulobas Community Forest (CF), Bardiya National Park was also conducted. The informal interviews consisted of discussion on Army's involvement in conservation of their CF and their perception on Army's involvement.

Figure 1: A schematic diagram of the method undertaken in the study 


\section{Conservation overview of Nepal}

In the following paragraphs, the conservation overview of Nepal will be provided. Essentially, how Nepal has undergone a paradigm shift in conservation has been outlined. Conservation is the act of protecting the natural environment and its resources along with proper use. At first, the fortress style of protection measures was in place which has gradually transformed into other approaches.

Initially, prized games were protected in the forests of Chitwan and Bardiya in Nepal to serve as hunting grounds for the ruling elites. These eventually changed to fortress style of protection measures. Essentially, this meant excluding the indigenous people who had been living in these regions out of their lands. There has been a paradigm shift in conservation in Nepal with initially, protection of pristine area through strict control, then embracing conservation and development, followed by participatory conservation, next adopting a landscape approach to conservation, and recently to additions of Protected Area network (Bhattarai et al., 2017). Dongol \& Neumann (2021) add, now the shift is towards securitization and away from Communitybased Conservation (CBC).

The National Parks and Wildlife Conservation Act 2029 (NPWCA) was ratified in 1973 and Nepal's first National Park, the Royal Chitwan National Park was established in 1973. The act was strict, restrictive and followed the Yellowstone model. Pristine area protection was emphasized and people living inside the park were prevented (Heinen, 1996; McNeely, 1994). This saw mass evacuation of people from the national park and reserves. 650 people residing in Rara National Park were relocated to the lowland of Banke district probably resulting in deaths of people brought about by environmental and socio-cultural stress (Heinen \& Kattel, 1992). Nepal Army started to be deployed for park management. A command and control approach followed for the enforcement of rules and regulations in the newly formed protected areas.

However, as the mid-1970s approached, it was deemed not possible to relocate all population residing in the protected areas as seen during establishment of Langtang and Sagarmatha National Parks. The locals were instead recognized as an integral part of protected area management. Amendments were made in NPWCA granting people rights to collect resources such as thatch grass and reeds from the reserves once a year. This is considered a pioneering step towards a people-centered approach. In the 1980s, the Department of National Parks and Wildlife Conservation (DNPWC) endorsed the Bali Action Plan striving for dual purposes - conservation and development. Nepal further experimented with the concept of Conservation Area. This concept included involvement of local people in conservation and development planning for the protected area and placed the authority of management of the Protected Area to a Non-Government Organization (NGO) now called the National Trust for Nature Conservation (NTNC).

Strict protection policy helped re-establish the depleted wildlife but this also meant increased human wildlife interaction (Gurung et al., 2008). In the lowlands where the interaction was most severe, the Park and People Project were launched. Political changes also brewed in Nepal with the overthrow of the partyless monarchy known as the Panchayat system by a multiparty democratic system. Against this backdrop, the NPWCA was also revised in 
1993 which allowed for declaration of buffer zones around protected areas. This allowed for people's access to natural resources and lessening for human wildlife interactions.

In the 2000s, a shift towards a site-based conservation to a landscape-scale approach began with the initiation of Terai Arc Landscape (TAL) project. Transboundary protected areas began to emerge and the Nepalese Government took steps towards a community management of protected areas.

The 2010s saw the protection of forests with significant biological, cultural and religious values. The areas are utilized by locals for resources and also serve as biological corridors for iconic species. Not a paradigm shift per se but Dongol \& Neumann (2021) note that post the People's War or the Nepalese Civil War, the shift has been towards securitization. Restrictive access to subsistence from the forest has been observed with use of disciplining practice and surveillance tool in wide practice. The trend of hardening of authoritarian approach of conservation is much like reverting back towards the earlier models of exclusionary approach.

\section{Nepal Army in Conservation}

In the preceding section, Nepal's conservation overview was discussed. In the following paragraphs, Nepal Army's role in conservation, perception on their involvement and the present militarization of conservation is outlined.

\section{Nepal Army's work in conservation}

Nepal Army had been part of conservation efforts since 1975 being stationed in several protected areas in the country. Nepal's internal conflict namely the Nepalese Civil War(1996-
2006) constrained the conservation efforts of Nepal Army. With the improvement in the internal security scenario, their involvement has swamped back. Presently 7,627 army personnel are deployed in 10 national parks, 3 conservation areas and 6 protected forests (Ghale, 2018).

During Nepalese Civil War (1996-2006), Nepal Army had to be deployed for internal security which saw an increase in smuggling, poaching, and hunting (Upreti, 2004, 2009; Yonzon, 2004). A 32\% decline in Nepal's rhino population from 2000-2005 were reported as a result of poaching (Mainali, 2005). Now, the rhino population has sprung to 752 . Hence, the Nepal Army has immensely contributed to prevention and control of wildlife poaching and trading. Likewise, Nepal Army are also involved in controlling encroachment and deforestation, promoting afforestation, supporting rehabilitation of wild species, supporting wildlife census amongst others.

Nepal Army has been supported by a lot of organizations such as through direct funds for physical infrastructure and equipment for surveillance and anti-poaching activities. The World Bank financed a 5-year project for material support (crime-control facility, patrol vehicles, computers, and guard posts) for combating wildlife crimes in 2011. The World Wildlife Fund (WWF) also provided funds for purchasing enforcement equipment for combating poaching and the illegal wildlife trade in the same year. Likewise, the USAID, in cooperation with WWFNepal and others, funded the USD 39 million "Hariyo Ban" project which has provided USD 70,000 for construction of facilities for the Army to be used in wildlife protection (Dongol \& Neumann, 2021). 
Nepal Army's work has not gone unnoticed. In the international platform as well, they have been honored for their contribution. WWF Leaders for a Living Planet had awarded two battalions and one company of the Nepal Army for playing an instrumental role in achieving this second year of zero poaching.

\section{Perception on Nepal Army's involvement}

While Nepal has embraced the concepts of a more holistic approach of local people participation in conservation efforts through formation of buffer zones, justice to the original exclusion is still not met. Illtreatment by the Nepal Army and National Park personnel protecting conservation areas has been registered (Amnesty International \& CSRC, 2021). The indigenous people have been frequently arrested and detained by the Nepal Army and park authorities for entering protected areas. Even deaths have resulted. UN (2010) had documented six murders by army personnel in the national parks of Terai, Nepal.

Women living near the parks are particularly vulnerable to violations. They are normally the ones who enter the forest daily for collection of resources. One such incident was the beating up of a local woman in Belsar Buffer Zone Community Forestry (BZCF) in Chitwan (Gurung, 2019). She claimed to be cutting grass in the forest and accused the soldier of trying to rape her. These incidents are not isolated events. UN (2010) also found the army was actively playing a role in obstructing criminal accountability.

These incidents apart from the gross human right violation are also threats to undermining conservation itself. Sonaha people living near the Bardiya National Park for instance have reported threats of the Army to not enter the forest. If found they would face arrest. Thing et al (2017) writes resistance has brewed amongst the Sonahas and they have been contravening the Park rules. This is not entirely because of the Nepal Army but the Nepal Army forms part of a system that has seen the need for resistance.

\section{Militarization of conservation}

Throughout the world, there is an ambivalence on militarization of conservation. Involving military and paramilitary actors, their partnership and training for conservation, and their use of technology is termed the 'green militarization' (Lunstrum, 2014). On the one hand, deploying army for conservation is seen as a robust way of dealing with poaching. Whether this is achieved or not such as Army's involvement in achieving zero poaching years in Nepal or the increasing rate of rhino poaching in the Kruger National Park, South Africa despite militarization, it is increasingly given much attention with each failure bringing another round of militarization. On the other hand, conflict with the community is registered with restrictions on resource use, arrests, detentions and even torture and death.

The trend towards militarization of conservation reflects hardening of authoritarian regimes which were dominant in colonial and early to middle postcolonial periods, representing a challenge towards the more decentralized CBC (Lunstrum, 2014). The call for militarization of conservation has also been fueled by commodification of nature conservation and is increasingly subject to commodification itself (Marijnen \& Verweijen, 2016).

Dongol \& Neumann (2021) write that there has been increasing militarization in protected 
areas and securitization in buffer zones in Nepal. They opine this as a way of securing Conservation Territory (CTs) for wildlife with the motive of securing them against future uprisings. Ojha et al (2021) describe that the trend of forest governance is moving towards resurrection of the centralized power. This increased Army presence has been noted to be 'intrusive and ubiquitous' with especially resource dependent women fearing encounters (Dongol \& Neumann, 2021). The growing militarization of conservation is reflected by the greater share of park's operation budget that the army has undertaken. In 1982-1983, the Army took $51 \%$ share of the park's operation budget, during the war years and beyond the budget share has increased to $80 \%$ (cited in Dongol \& Neumann, 2021).

In the Naulobas BZCF, increased presence of Army has also been noted. The reason stated is the protection of increased wildlife residing in the $\mathrm{CF}$. At this point, if the increased penetration is also because of securing CTs for motives as mentioned by Dongol \& Neumann (2021) and Ojha et al (2021) needs much more careful evaluation. The Sonaha community nearby Naulobas BZCF recall establishing a community forest for increasing access of the local people on availability of forest resources. Now that the $\mathrm{CF}$ is well established, much wildlife is abundant there. The locals said even a resident tiger resides there. Because of this, the Army have intervened for protection of the species. Increased patrolling and control over resource use is practiced. The locals feel their efforts of establishing a $\mathrm{CF}$ for resource use has gone in vain.

During a discussion with some locals in Sonaha Tol, a 46 years old local fisherman and farmer expressed his views on the increased Army intervention.
"It's like we planted the trees for the wildlife and not for our use."

Another resident of Sonaha Tol in her mid30 s lamented on the lack of access to natural resources now.

"Our access to natural resources is restricted now both because of the wildlife and the Army who patrol in our area. The point of Community Forest providing access to resources is lost on us."

With more Army's presence in the CTs, more interaction with the locals is bound to happen. This could make for an increase in Locals-Army conflict if accountability is not practiced. The increased possibilities of misuse of power could threaten civil-military relations.

\section{Rethinking the engagement}

In the preceding section, Nepal Army's role in conservation was highlighted. In the following paragraphs, views on rethinking their engagement has been presented with the instances of conservation and resource management without the involvement of Army and efforts seen and required for civilmilitary relations transformation.

\section{Conservation and resource management without the involvement of Army}

Nepal has also practiced conservation without the involvement of the Army. With operation of over 3.5 decades, Annapurna Conservation Area Project (ACAP) has been a successful CBC model globally. ACA is the first of the protected areas in Nepal which has not been protected by the Army, rather a voluntary compliance is in place. In comparison to cases of illegal hunting from Army guarded national parks and wildlife reserves, ACA's 
case is comparatively very low (Ojha \& Sarker, 2012). Rather an increasing growth of wildlife population has been seen.

However, the historical context of ACAP launch and the modality it adopted for achieving its goal of bringing sustained balance between nature conservation and socio-economic improvement is a point to be noted. Chitwan National Park was established to prevent the extinction of rhinos. At that time and even now involvement of the Army is considered the optimum course for combating the poaching of rhinos.

More than $30 \%$ ofthe earthisalready conserved by indigenous groups (ICCA Consortium, 2021). Environmental stewardship by indigenous peoples and local communities have also showcased more success in achieving conservation outcomes than run by external actors (Dawson et al., 2021). Nepalese indigenous population comprise $35.8 \%$ of the population of the country ( $\mathrm{GoN}$, 2018) and many have ingrained conservation philosophies into them. The indigenous communities have profound connections with their land. The aforementioned residents or their descendants who were shifted to the lowland of Banke district during the creation of Rara National Park still trek across the mountains to worship their ancestral gods (Shrestha, 2018).

The Tsumbas of the Tsum Valley, Nepal for instance practice conservation of nature as a part of their daily life and spiritual commitment. The nature-culture conservation is being sustained through 'Shyagya' tradition or the culture of non-violence (Rai \& Lama, 2021). Likewise, long before Shey Phoksundo National Park was established, the conservation was grounded by local tradition. Bon Po, a pre-Buddhist religion in Dolpo has enabled conservation as a deep reverence for nature is deep-rooted in their belief system (Lama, 2019).

Moreover, Nepal also has a unique system of managing water for irrigation which is known as the Farmers Managed Irrigation System (FMIs). In this case, farmers themselves manage the irrigation systems by engaging in collective choice action. The share of both the costs and benefits from the systems is in proportion (Ostrom et al., 1994; Ostrom \& Gardner, 1993). FMIs thus functions as a grass-root level democratic institution and is one of the most successful models of common pool resource use.

\section{Efforts for Civil-military relations transformation}

Failure in critically evaluating militarization has been noted to possibly lead towards poor conservation outcomes (Duffy et al., 2019). Sonahas in Bardiya for instance have a resistance movement as noted in preceding sections. Referred to as 'everyday resistance' by Scott (1986), this includes contravening park rules, continuing customary occupation and using resources. Lack of accountability of the Army could further fuel the resistance movement.

Recently, it is also seen that the Army is increasing their effort for minimizing conflicts with the locals. They have been implementing health check post, awareness programs, contributing in disaster risk management amongst others which has helped in minimizing conflicts with locals (Pokhrel, 2020). However, efforts should be made in accountability and reformation of the legal framework.

There is a gap in the domestic legal framework in the regulation of Nepal Army to arrest 
and detain people, and use of lethal force. There are provisions of immunity for officers who claim to have no alternative but to shoot anyone found breaching provisions of NPWCA even if it means death. This clearly needs redress. In the context of enforcing conservation laws, if violations of human rights have been alleged by Nepal Army then there needs to be a prompt and independent criminal investigation. Provided sufficient admissible evidence has been obtained then prosecution in fair trials needs to be applied.

Way back, Wells \& Sharma (1998) had opined that the future of conservation largely depended on the effectiveness of the support from the locals. Rightly so, conservation success in Nepal is not just because of one institution, it's an amalgamation but the role of community has been largely uncredited. Misuse of power threatens local people and conservation. This calls for sufficient check and balance of power executed by armed personnel (Subedi, 2020).

And it is not just that the Army are the only ones who have made the conservation effort successful. Community Based Anti-Poaching Operation (CBAPO) or Community Based Anti-Poaching Unit (CBAPU) for instance have significantly contributed to wildlife conservation through activities such as patrolling, surveillance, rescue of wildlife etc. (Lamichhane et al., 2020). This has aided the Nepal Army to undertake conservation activities as well. Alienating locals through ill-treatment could also see less support from locals on conservation.

\section{Concluding remarks}

There is a need for substantial orientation of the Nepal Army's involvement in conservation. Their contribution to conservation although substantial requires a mandate for placing accountability. The Army's presence in the CTs is increasing which will result in more interaction with locals. Not practicing accountability has a possibility of threatening civil-military relations. In the changing social-ecological context, in order for the military in conservation to be relevant it is important to have substantial reorientation.

In the long run such accountability will enable enhanced conservation through cooperation from the local communities and their involvement as guardians. Lack of accountability opens up the possibilities of misuse of power which has devastating impacts on local and indigenous communities and may also impact conservation itself. Entities who have been supporting their role should also make it their mandate to hold them accountable for their action. Accountability should not be considered a restriction; these should be considered as a way to better function with the people. Joint operations with locals with engagement such as CBAPU could be an even more effective way for curbing poaching and other threats. Garnering such local support vests on amicable civil-military relations.

\section{References:}

Amnesty International, \& CSRC. (2021). Violations in the name of conservation. Amnesty International.

Bhattarai, B. R., Wright, W., Poudel, B. S., Aryal, A., Yadav, B. P., \& Wagle, R. (2017). Shifting paradigms for Nepal's protected areas: History, challenges and relationships. Journal of Mountain Science, 14(5), 964-979. https:// doi.org/10.1007/s11629-016-3980-9

Dawson, N., Coolsaet, B., Sterling, E., Loveridge, R., Gross-Camp, N., Wongbusarakum, S., Sangha, K., Scherl, L., Phan, H., ZafraCalvo, N., Lavey, W., Byakagaba, P., Idrobo, 
C. J., Chenet, A., Bennett, N., Mansourian, S., \& Rosado-May, F. (2021). The role of Indigenous peoples and local communities in effective and equitable conservation. Ecology and Society, 26(3). https://doi.org/10.5751/ ES-12625-260319

Dongol, Y., \& Neumann, R. P. (2021). State making through conservation: The case of post-conflict Nepal. Political Geography, 85, 102327. https://doi.org/10.1016/j. polgeo.2020.102327

Duffy, R., Massé, F., Smidt, E., Marijnen, E., Büscher, B., Verweijen, J., Ramutsindela, M., Simlai, T., Joanny, L., \& Lunstrum, E. (2019). Why we must question the militarisation of conservation. Biological Conservation, 232, 66-73. https://doi.org/10.1016/j. biocon.2019.01.013

Ghale, S. (2018). Men in green. The Kathmandu Post. https://kathmandupost.com/ opinion/2018/05/22/men-in-green

Government of Nepal. (2018). Alternative Report of the Indigenous Peoples of Nepal. https://tbinternet.ohchr.org/Treaties/CERD/ Shared\%20Documents/NPL/INT_CERD_ NGO_NPL_30811_E.pdf

Gurung, B., Smith, J. L. D., McDougal, C., Karki, J. B., \& Barlow, A. (2008). Factors associated with human-killing tigers in Chitwan National Park, Nepal. Biological Conservation, 141(12), 3069-3078.

Gurung, T. D. (2019). Nepali park officials tortured a man to death. Then, the government and the World Wide Fund for Nature rewarded them. https://kathmandupost.com/ investigations/2019/03/03/nepals-parkofficials-who-beat-and-tortured-a-man-wererewarded-by-the-government-and-the-worldwide-fund-for-nature
Heinen, J. T. (1996). Human behavior, incentives, and protected area management. Conservation Biology, 10(2). .

Heinen, J. T., \& Kattel, B. (1992). Parks, people, and conservation: A review of management issues in Nepal's protected areas. Population and Environment, 14(1), 49-84.

ICCA Consortium. (2021). Territories of Life: 2021 Report. ICCA Consortium: Worldwide. Report.. .

Lama, S. C. (2019). Bon voyage.heinen Nepali Times. https://www.nepalitimes.com/banner/ bon-voyage/

Lamichhane, S., Joshi, R., Poudel, B., \& Subedi, P. (2020). Role of Community in Leading Conservation: Effectiveness, Success and Challenges of Community-Based AntiPoaching Unit in Nepal.

Lunstrum, E. (2014). Green Militarization: AntiPoaching Efforts and the Spatial Contours of Kruger National Park. Annals of the Association of American Geographers, 104(4), 816-832. https://doi.org/10.1080/000 45608.2014.912545

Mainali, K. P. (2005). Sharp Decline in Nepal's Rhino Population. Research Gate 3(5). https://www.researchgate.net/ publication/269964491_Sharp_Decline_in_ Nepal's_Rhino_Population

Marijnen, E., \& Verweijen, J. (2016). Selling green militarization: The discursive (re) production of militarized conservation in the Virunga National Park, Democratic Republic of the Congo. Geoforum, 75, 274-285. https:// doi.org/10.1016/j.geoforum.2016.08.003

McNeely, J. A. (1994). Protected areas for the 
21st century: Working to provide benefits to society. Biodiversity \& Conservation, 3(5), 390-405.

Ojha, A. P., \& Sarker, T. K. (2012). Effectiveness of the Integrated Conservation and Development Program (ICDP) in conserving wildlife in the Annapurna Conservation Area in Nepal. International Journal of Biodiversity and Conservation, 4(6). https://doi.org/10.5897/ IJBC 11.060

Ojha, H., \& Hall, A. (2021). Transformation as system innovation: Insights from Nepal's five decades of community forestry development. Innovation and Development, 1-23. https:// doi.org/10.1080/2157930X.2021.1917112

Ostrom, E., \& Gardner, R. (1993). Coping with Asymmetries in the Commons: SelfGoverning Irrigation Systems Can Work. Journal of Economic Perspectives, 7(4), 93112. https://doi.org/10.1257/jep.7.4.93

Ostrom, E., Lam, W. F., \& Lee, M. (1994). The Performance of Self-Governing Irrigation Systems in Nepal. Human Systems Management, 13(3), 197-207. https://doi. org/10.3233/HSM-1994-13305

Pokhrel, M. (2020, January 15). Civil-military relations transform in Nepal's Chitwan Park. The Third Pole. https://www.thethirdpole.net/ en/nature/civil-military-relations-transformin-nepals-chitwan-park/

Rai, J. K., \& Lama, N. (2021). Tsum Valley: Nature-culture stewardship of the Tsumba people in the Western Himalaya, Nepal. In Territories of Life: 2021 Report. ICCA Consortium.
Scott, J. (1986). Everyday forms of peasant resistance. The Journal of Peasant Studies, 13(2), 5-35.

Shrestha, S. (2018). Living in the shadow of Nepal's Rara National Park. Al Jazeera. https:// www.aljazeera.com/features/2018/4/29/ living-in-the-shadow-of-nepals-rara-nationalpark

Subedi, H. (2020). A Hayekian Critique of the Mode of Biodiversity Conservation in Nepal (SSRN Scholarly Paper ID 3736096). Social Science Research Network. https://doi. org/10.2139/ssrn.3736096

Thing, S. J., Jones, R., \& Jones, C. B. (2017). The Politics of Conservation: Sonaha, Riverscape in the Bardia National Park and Buffer Zone, Nepal. Conservation and Society, 15(3), 292303.

UN. (2010). Investigating Allegations of Extra-Judicial Killings in the Terai. https:// nepal.ohchr.org/en/resources/publications/ Investigating $\% 20$ Allegations $\% 20$ of $\% 20$ Extra-Judicial\%20Killings\%20in\%20the\%20 Terai.pdf

Upreti, B. R. (2004). The price of neglect: From resource conflict to Maoist insurgency in the Himalayan kingdom. Bhrikuti Academic Publications.

Upreti, B. R. (2009). Impacts of Armed Conflict on Mountain Biodiversity: Experiences from Nepal. Rhino, 128(128), 256.

Wells, M. P., \& Sharma, U. R. (1998). Socioeconomic and political aspects of biodiversity conservation in Nepal. 18.

Yonzon, P. (2004). Threats to Nepal's protected areas. Parks, 14(1), 35-39. 